\title{
Characterization of $\mathrm{MnCo}_{2} \mathrm{O}_{4}$ as anode material for a Sodium- Air Electric Vehicle Battery
}

Han Peng*

School of Mechanical Engineering, North China University of Water Resources and Hydropower, Dengzhou City, Henan Province, 450045, P.R. China

*E-mail: $727787302 @$ qq.com

doi: $10.20964 / 2018.04 .13$

Received: 7 December 2017 / Accepted: 29 January 2018 / Published: 6 March 2018

\begin{abstract}
Among multiple next-generation rechargeable energy storage systems (e.g., electric vehicle battery), one substitution for lithium-ion batteries (LIBs) is the sodium-ion battery (SIBs). However, the thermodynamic and kinetic properties of SIBs remain uncertain, considering the distinct (de)sodiation processes and larger ionic radius of the sodium cation. The present work demonstrates the fabrication of inorganic $\mathrm{MnCo}_{2} \mathrm{O}_{4}$ nanoparticle-based SIBs. Under dry air experimental conditions, the $\mathrm{MnCo}_{2} \mathrm{O}_{4} / \mathrm{C}$-air electrode showed a high initial discharge capacity $(7502 \mathrm{~mA} / \mathrm{h} / \mathrm{g})$ and a stable working voltage $\left(\sim 2.1 \mathrm{~V}\right.$ against $\left.\mathrm{Na}^{+} / \mathrm{Na}\right)$.
\end{abstract}

Keywords: Sodium-air batteries; $\mathrm{MnCo}_{2} \mathrm{O}_{4}$; Electric vehicle battery; Charge-discharge

\section{FULL TEXT}

(C) 2018 The Authors. Published by ESG (www.electrochemsci.org). This article is an open access article distributed under the terms and conditions of the Creative Commons Attribution license (http://creativecommons.org/licenses/by/4.0/). 